\title{
Sydkaukasien: frihet och säkerhet i stormakternas skugga?
}

\author{
Christofer Berglund ${ }^{\star}$ \\ Institutionen för Globala politiska studier, Malmö universitet, Sverige
}

Länderna i Sydkaukasien - Armenien, Azerbajdzjan och Georgien - går sedan länge en svår säkerhetspolitisk balansgång. Respektive land måste utöver sin komplicerade relation till varandra navigera mellan konkurrerande grannar som Ryssland och EU. Den förra ser på regionen som sitt "nära utland» och den senare ser på den som sitt "östliga partnerskap".

De bägge stormakterna skiljer sig dock åt på väsentliga sätt. Ryssland är den historiskt dominanta grannen. Föreställningen att regionen tillhör dess intressesfär går att spåra åtminstone tillbaka till 1800-talet (Oskanian, 2018). Under 1990-talet konceptualiserades därför de suveräna stater som tog sovjetrepublikernas plats som Rysslands "nära utland" (blizjneje zarubezje). Ett veritabelt lexikon finns för att fånga nationens diffusa gränser (Safire, 1994; CNA, 2015; Kolstø, 2016, s. 18). Till dess kärna hör såklart de etniska ryssarna (russkije) men även medborgare med annat ursprung (rossijane) samt ett stort antal landsmän (sootetjestvenniki) i det nära utlandet som sägs ingå i den större ryska världen (russkij mir). ${ }^{1} \mathrm{Kreml}$ drar sig inte för att slå in dörren till sina forna kolonier för att diktera inriktningen på deras politik med hänvisning till dessa gruppers väl och ve, vilket 2008 års krig mot Georgien och 2014 års krig mot Ukraina illustrerar (Medvedev, 2008; Putin, 2014). Denna preferens för piskan (framför moroten) som påverkansinstrument påminner om atenarnas position i den meliska dialogen om det peloponnesiska kriget: "de mäktigare tar för sig allt de kan medan de svaga blott har att finna sig i det» (citerat i Nye, 2007, s. 20).

Mot denna realpolitiska stormakt står en idealpolitisk dito, EU, som söker locka länderna i sin närhet till reformer genom den europeiska grannskapspolitiken (ENP). Den riktar sig sedan 2009 mot Armenien, Azerbajdzjan och Georgien - men inbegriper även Belarus, Moldavien och Ukraina - inom ramen för det "östliga partnerskapet» (ÖstP). Eftersom unionens medlemsländer binds samman genom delade ${ }^{1}$ Ett annat begrepp i detta lexikon är "Nya Ryssland» (Novorossija) som Putin började bruka år
2014 för att referera till landmassan i södra Ukraina mellan Azovska sjön och Svarta havet.

^Kontaktinformasjon: Christofer Berglund, epost: christofer.berglund@mau.se 
värderingar, och förlitar sig på internationella institutioners förmåga att sprida dessa, ses EU som en "normativ» makt (Manners, 2002). Preferensen för moroten (framför piskan) som påverkansinstrument innebär att unionen talar ett helt annat språk än Kreml i sina relationer till länderna i grannskapet. Men det östliga partnerskapets resultat under det gångna decenniet imponerar inte. I "föregångsländer» som Georgien och Moldavien kontrollerar oligarkiska schatteringar regeringsmakten och manipulerar rättsväsendet (Bolkvadze, 2016, 2020).

Situationen väcker ett antal angelägna frågor. Kommer Ryssland att kunna behålla kontrollen över sitt "nära utland»? Kan EU lära sig att hantera den geopolitiska tvekamp som unionen dragits in i? Och hur navigerar den politiska eliten i Sydkaukasien mellan sina grannar? Dessa frågor angrips inom ramen för detta temanummer som inkluderar originella bidrag från Jakob Hedenskog (FOI Totalförsvarets forskningsinstitut), Michel Anderlini (Malmö universitet), Per Ekman (Uppsala universitet) och Li Bennich-Björkman (Uppsala universitet).

Hedenskog (2020) driver tesen att Kreml hittills inte lämnat något tvivel om vare sig sin vilja eller förmåga att kontrollera Sydkaukasien. Regionen är avgörande för Rysslands nationella intressen både i defensivt och offensivt hänseende. Kreml fruktar att statens territoriella integritet står på spel i Kaukasien, liksom under 1990-talets Tjetjenienkrig. En framgångsrik separatiströrelse här riskerar att få dominoeffekter. ${ }^{2}$ Eftersom flera folkgrupper är spridda på båda sidor Kaukasusbergen - däribland osseterna - räcker det inte heller med att kontrollera Nordkaukasien. Sydkaukasiens politiska vägval får omedelbara konsekvenser för Ryssland. ${ }^{3}$ Om NATO skulle uppta ett land söder om bergskedjan kommer alliansens infrastruktur ännu närmare federationens gränser. Kreml uppfattar därför protester mot regimer i sitt "nära utland» som brohuvuden för transatlantisk expansion. Det blir sålunda nödvändigt att försvara sin regionala hegemoni för att få erkännande som stormakt.

Kreml använder militära, politiska och ekonomiska instrument för detta ändamål. Dess närmaste partner i regionen är Armenien som är medlem i Organisationen för det kollektiva säkerhetsavtalet (CSTO) och köper vapen till reducerade priser. Jerevan är beroende av militärt och politiskt stöd från Kreml på grund av NagornoKarabach-konflikten, som lett till ett embargo från både Azerbajdzjan och Turkiet. Ryssland har också ett ekonomiskt grepp om Armenien, som år 2013 tvingades dra sig ur ett planerat associeringsavtal med EU för att sedan ansluta sig till Euroasiatiska ekonomiska unionen (EAEU). Azerbajdzjan har större handlingsfrihet tack vare sin energirikedom. Baku exporterar olja och gas till Europa som därmed hamnar i beroendeställning till den auktoritära regimen. Azerbajdzjan är inte med i vare sig CSTO

\footnotetext{
${ }^{2}$ Denna insikt motiverar till en strategi som går ut på att statuera avskräckande exempel, och är karaktäristisk för stater som konfronterar flera separatiströrelser (Walter, 2003).

${ }^{3}$ "Jag kan bara försvara mina gränser genom att expandera dem" som tsardömets Katarina den stora sägs ha upptäckt redan under 1700-talet (se Cooper, 2004, s. 78).
} 
eller EAEU men har en stark relation till Ryssland som säljer vapen också till Baku. Georgien utgör den främsta utmaningen för Kreml. Vare sig ekonomiska sanktioner eller politiska påstötningar har förmått Tbilisi att ändra sin pro-västliga kurs mot NATO och EU. 2008 års invasion och erkännandet av separatistregimerna i Abchazien och Sydossetien innebar att Kreml infriade hotet att "slita sönder de stater som önskar lämna Moskvas intressesfär» (Goltz, 1993, s. 92). Det rumphuggna Georgien har emellertid ingått ett associeringsavtal med EU och tillhör föregångsländerna i det "östliga partnerskapet».

Misstron mot Rysslands avsikter är utbredd i Sydkaukasien. Inte minst eftersom Kreml ofta spelar ut stater och folkgrupper mot varandra. Men dess svaga attraktionskraft kompenseras genom stark tvångsmakt. Rysslands södra militärdistrikt innefattar tre baser söder om Kaukasusbergen - 102:a militärbasen i Armenien, 7:e militärbasen i Abchazien och 4:e militärbasen i Sydossetien - med förlagrad utrustning som räcker för att hantera regionala konflikter och mer därtill. Detta vittnar om Kremls beslutsamhet, menar Hedenskog.

Vad har då EU för möjligheter att omdana länderna i det "östliga partnerskapet» efter egen modell? Anderlini (2020) tar sig an detta spörsmål. Han hävdar att ÖstP fokuserar allt mindre på partnerskapsländernas integration med EU och allt mer liknar traditionell utrikespolitik. När grannskapspolitiken togs fram under 2000-talet så skedde det med utvidgningen i Central- och Östeuropa som mall. Politisk konditionalitet i kombination med finansiellt och tekniskt stöd skulle inspirera till demokratisering. Men förhoppningen har kommit på skam. Lokala oligarker motarbetar reformer och Kreml har flera gånger fått partnerskapsländerna att vika ned sig, t.ex. när Armenien och Ukraina lämnade de framförhandlade associeringsavtalen under 2013. EU måste därför lära sig att handskas med geopolitik - men utan att överge sin idealpolitiska kärna, som är garanten för att små stater inte offras för maktbalansens skull.

Anderlini spårar denna lärandekurva genom att fokusera på unionens kapacitet, regionala tillfällen och inhemska intressegrupper i Armenien, Azerbajdzjan och Georgien. Han konstaterar att normöverförande processer till dessa länder aldrig understötts med ett löfte om EU-medlemskap. Även när unionen lockat med tillgång till den inre marknaden och viseringsfrihet har konditionalitetsprincipen inte tillämpats konsekvent. Det är främst i Georgien, som står i ett ensidigt beroendeförhållande till unionen och saknar andra regionala allierade att luta sig mot, som normöverföringen gjort framsteg. Men även här finns inhemska intressegrupper politiska eliter, näringslivstoppar, statstjänstemän - som ibland sätter sig på tvären, vilket resulterar i ofullständiga reformer. EU:s transformativa potential förefaller ha nått sin gräns. Men det ställer föregångsländer som Georgien, som efterfrågar medlemskap som slutdestination, inför en reell risk att bli lämnad vid altaret.

Hur kommer det sig då att varje regering som utnämnts i Tbilisi sedan mitten på 1990-talet insisterat på att föra en pro-västlig utrikespolitik? Ekman (2020) griper sig an detta pussel. Små stater anses ofta nödgade att anpassa sig till regionala 
stormakter, likt Finland till Sovjetunionen efter andra världskriget, när deras geografiska läge gör det svårt att finna allierade som kan fungera som en trovärdig motbalans (Walt, 1987). Akademiker brottas därför med att förklara varför Georgien dristar sig till att blicka västerut trots att man saknar pålitliga ingångar till NATO och EU. Landets europeiska identitet och ledande politikers bakgrund har anförts som möjliga orsaker. Ekman gör dock gällande att dessa förklaringar missar en väsentlig pusselbit, nämligen att det kollektiva minnet av den formativa frigörelsen från Sovjetunionen omöjliggör andra säkerhetspolitiska vägval.

Traumatiska erfarenheter tenderar att etsa sig fast i den nationella identiteten, särskilt när upplevda oförrätter är involverade. De resulterar i tankemönster som identifierar offer, förövare och befriare och baserar sig i regel på en selektiv förståelse av det förflutna. Konsekvensen är icke desto mindre att vissa utrikespolitiska strategier framstår som mer (o)acceptabla än andra. Ekman argumenterar för att Georgiens pro-västliga kurs kan förstås genom denna infallsvinkel. Intervjuer med ledande politiska beslutsfattare i Tbilisi visar att dessa ser Georgien som ett offer i 1990-talets inbördeskrig och Ryssland som förövare med avsikt att tvinga dem till underkastelse. ${ }^{4}$ Utifrån denna prisma är de mest acceptabla lösningarna att antingen fly eller bekämpa Kreml. Den transatlantiska och europeiska gemenskapen i form av NATO och EU är potentiella befriare i denna strävan. Georgiens utrikespolitik uppvisar anmärkningsvärd kontinuitet över tid eftersom man - trots flera regeringsskiften - inte vikit från den pro-västliga stig som tankemönstret ovan påbjuder.

Bennich-Björkman (2020) riktar blicken mot ett land som gjort helt andra vägval, Armenien, men vars säkerhetspolitiska kompass har varit föremål för intensiva diskussioner sedan "sammetsrevolutionen" i april 2018. Protestaktioner mot den sittande presidenten Serzj Sargsian kulminerade då i ett regeringsskifte som förde Nikol Pasjinjan till makten. Eftersom händelseförloppet påminde om tidigare färgrevolutioner i det "nära utlandet» inställde sig frågan hur Kreml skulle reagera. ${ }^{5}$ Pasjinjan har noggrant betonat att revolutionen har inhemska rötter och inte handlar om att ändra utrikespolitisk kurs (Abrahamyan \& Melikyan, 2018). Den är såtillvida "färglös». I vilken utsträckning har då den påstådda omvälvningen - "revolutionen» egentligen förändrat elitens säkerhetspolitiska mentalitet?

Bennich-Björkman undersöker denna högaktuella fråga genom unikt enkätmaterial och intervjuer som riktats till landets eliter före (2017) och efter (2019) omvälvningen. Datainsamlingen, som genomförts i samarbete med Caucasus Research Resource Centers, fokuserar på elitens inställning både till territoriell och humanitär säkerhet. Tolerans mot utsatta grupper, däribland kvinnor och sexuella

\footnotetext{
${ }^{4}$ Perspektivet innebär att den georgiska sidans roll i konfliktförloppet sällan blir föremål för kritisk reflektion i Tbilisi. Osseterna och abchazerna betraktas inte som väsentliga aktörer i sammanhanget och deras klagomål tas därför sällan i beaktande (Berglund, 2016, s. 92).

${ }^{5}$ Rysslands militärdoktrin (2014) nämner inrättandet av regimer, vars politik hotar federationens intressen i det nära utlandet, som en risk ( $(12$, se $\mathrm{m}$ men även $\mathrm{a}, \mathrm{c}$ och $\mathrm{i})$.
} 
minoriteter, ses nämligen ofta som en förelöpare till nationell säkerhet (Hudson, Caprioli, Ballif-Spanvill, McDermott \& Emmett, 2008). Forskningsresultaten ger dock inte grund för optimism på någon punkt. Eliterna förväntar sig fortfarande att kvinnor (oaktat karriär) ska axla ansvar för hushållet, och sexuella minoriteter anses propagera för sin läggning. Få ser Armenien som europeiskt och viljan att förhandla med Baku är obefintlig. De enda acceptabla lösningarna är att annektera eller erkänna Karabach. Jerevan ser därför ut att förbli låst i sitt strukturella beroendeförhållande till Ryssland utan anmärkningsvärda förändringar i sin säkerhetspolitiska kompass efter "sammetsrevolutionen".

Bidragen i detta temanummer drar uppmärksamhet till en geografiskt perifer men geopolitiskt central region. Sydkaukasien må vara förpassad till Rysslands "nära utland» och EU:s "östliga partnerskap». Men det faktum att dessa föreställningar överlappar gör länderna i regionen till en tektonisk kollisionszon, som är angelägen att studera eftersom de konkurrerande stormakterna talar olika - realpolitiska respektive idealpolitiska - språk. Det är min förhoppning att dessa bidrag ska öka förståelsen för dessa språk, liksom för den svåra struktur som politiska beslutsfattare i Armenien, Azerbajdzjan och Georgien har att navigera.

\section{Referenser}

Abrahamyan, E. \& Melikyan, G. (2018). Moscow worries Armenian 'velvet revolution' could lessen its leverage over Yerevan. Eurasia Daily Monitor (3 maj).

Anderlini, M. (2020). Möjligheter och begränsningar för EU:s aktörskap i Södra Kaukasus. Nordisk Østforum.

Bennich-Björkman, L. (2020). Säkerhet och sårbarhet efter Armeniens Sammetsrevolution: Hur ser eliterna på konfliktlösning, jämställdhet och mänskliga rättigheter? Nordisk Østforum.

Berglund, C. (2016). Borders and belonging: Nation-building in Georgia's Armenian and Azerbaijani ethno-regions, 2004-2012. Uppsala: Uppsala universitet.

Bolkvadze, K. (2016). Cherry picking EU conditionality: Selective compliance in Georgia's hybrid regime. Europa-Asia Studies, 68(3), 409-440.

Bolkvadze, K. (2020). To reform or to retain? Politicians' incentives to clean up corrupt courts in hybrid regimes. Comparative Political Studies, 53(3-4), 500-530.

CNA. (2015). Mobilizing compatriots: Russia's strategy, tactics, and influence in the former Soviet Union. Arlington: CNA Corporation.

Cooper, R. (2004). The breaking of nations: Order and chaos in the 21st century. London: Atlantic Books.

Ekman, P. (2020). Trauma och kollektiva minnen i Georgiens utrikespolitik. Nordisk Østforum.

Goltz, T. (1993). Letter from Eurasia: The hidden Russian hand. Foreign Policy, 92, 92-116.

Hedenskog, J. (2020). Rysslands hanterande av sin intressesfär i Sydkaukasien. Nordisk Østforum.

Hudson, V., Caprioli, M., Ballif-Spanvill, B., McDermott, R. \& Emmett, C. (2008). The heart of the matter: The security of women and the security of states. International Security, 33(3), 7-45.

Kolstø, P. (2016). Introduction: Russian nationalism is back - but precisely what does that mean? I P. Kolstø \& H. Blakkisrud (Red.), The new Russian nationalism: Imperialism, ethnicity and authoritarianism 2000-2015 (s. 18-45). Edinburgh: Edinburgh University Press.

Manners, I. (2002). Normative power Europe: A contradiction in terms? fournal of Common Market Studies, 40(2), 235-258.

Medvedev, D. (2008). Interview given by Dmitry Medvedev to Television Channels Channel One, Rossia, NTV. 31 augusti. Hämtat den 18 juli 2020 från http://www.en.kremlin.ru/events/president/transcripts/ statements $/ 48301$.

Nye, J. (2007). Understanding international conflicts. New York: Pearson Longman.

Oskanian, K. (2018). A very ambiguous empire: Russia's hybrid exceptionalism. Europe-Asia Studies, 70(1), $26-52$. 


\section{8 | CHRISTOFER BERGLUND}

Putin, V. (2014). Address by President of the Russian Federation. 18 mars. Hämtat den 18 juli 2020 från http:// en.kremlin.ru/events/president/news/20603.

Rysslands militärdoktrin. (2014). The military doctrine of the Russian Federation. Approved by the President of the Russian Federation on December 25 (No. Pr.-2976). Hämtat den 18 juli 2020 från https://rusemb. org.uk/press/2029.

Safire, W. (1994, 22 maj). On language: The near abroad. The New York Times. Hämtat den 18 juli 2020 från https://www.nytimes.com/1994/05/22/magazine/on-language-the-near-abroad.html.

Walt, S. (1987). The origins of alliances. Ithaca: Cornell University Press.

Walter, B. (2003). Explaining the intractability of territorial conflict. International Studies Review, 5(4), 137-153. 